a

Dyeing of Snow Surfaces to Observe Structure

Austin Kovacs

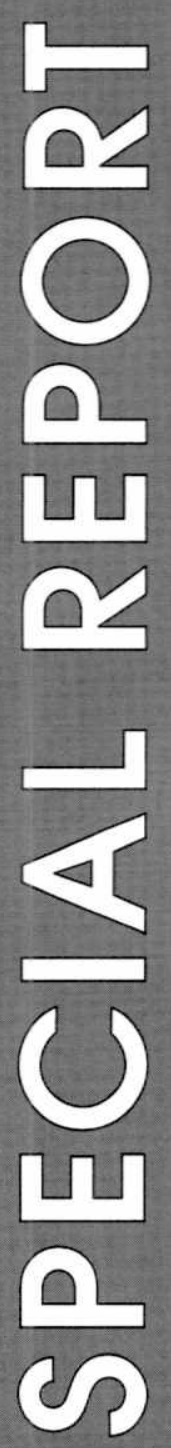




\section{Abstract}

A surface coloring method is described for highlighting the natural stratigraphy and load-induced structure in snow at low ambient temperatures in confined areas. The method includes planing the wall of a snow pit and then dyeing the surface using an alcohol dye applied by an electric sprayer. Surface heating and backlighting are also discussed as methods for revealing hidden detail, especially when photographic evidence of the snow structure is important.

For conversion of SI metric units to U.S./British customary units of measurement consult ASTM Standard E380-89a, Standard Practice for Use of the International System of Units, published by the American Society for Testing and Materials, 1916 Race St., Philadelphia, Pa. 19103. 


\section{Special Report 93-9}

U.S. Army Corps of Engineers

Cold Regions Research \& Engineering Laboratory

\section{Dyeing of Snow Surfaces to Observe Structure}

Austin Kovacs

June 1993 


\section{PREFACE}

This report was prepared by Austin Kovacs, Research Civil Engineer, Applied Research Branch, Experimental Engineering Division, U.S. Army Cold Regions Research and Engineering Laboratory.

The author acknowledges Donald Rissling and Sherwood C. Reed for their thoughts on the dyeing of snow surfaces and the review comments by Paul Richmond and Sally A. Shoop.

The contents of this report are not to be used for advertising or promotional purposes. Citation of brand names does not constitute an official endorsement or approval of the use of such commercial products. 


\title{
Dyeing of Snow Surfaces to Observe Structure
}

\author{
AUSTIN KOVACS
}

\section{INTRODUCTION}

When undertaking research on snow accumulation or mechanics, investigators often find it important to obtain a clear visual perspective and to obtain good photographic evidence of the snow stratigraphy in the vertical wall of a snow pit. Studies of trafficability, snow accumulation, melt percolation and bearing capacity frequently require the observation of snow morphology, and smoking (sooting), backlighting, painting and dyeing the snow surface are several techniques that have been used for this (Bader 1954, Diamond et al. 1959, Benson 1962).

Vertical snow surfaces have been sooted using vehicular exhaust, smudge pots and burning oil rags near the snow wall, allowing some stratigraphic and deformation features to be seen. However, more detail is frequently desired. Spray painting of the snow surface found its place in some research studies, but it did not prove satisfactory in our snow pit observations. At temperatures below $-10^{\circ} \mathrm{C}$, the paint would become too viscous to apply properly. So, a snow surface dyeing method was developed; it is discussed here, as are methods of enhancing the finished appearance.

\section{REQUIREMENT}

Studies made at Camp Century, Greenland, on anchors (Kovacs 1967), footings (Kovacs and Ramseier 1968, Reed 1966) and pile foundations (Kovacs 1976) led to a need to obtain good visual and photographic views of natural snow stratigraphy and the morphology associated with various snow loading deformation processes. Smoking techniques could not be used in the below-surface trenches where the testing was done, for obvious reasons, so we tried dyeing the snow surface using writing ink diluted in methyl alcohol or methylene coloring dissolved in methyl alcohol. Alcohol was used as the liquid because of freezeup problems with water. We found that both coloring agents worked well; however, we preferred a methylenecolored agent because only a small quantity was needed to make a large quantity of dye.

Several different methylene dye colors were tried to see which would produce the best view of the snow surface. We found that the darker dye colors provided the best contrast for highlighting snow density variations, with methylene blue and green giving the best results. Other methylene dye colors, such as orange, yellow and red, tended to highlight the snow morphology less clearly.

The methylene dye powder and alcohol were mixed by stirring. Only a very small amount of coloring was required, as a solution that is too dark produces an undesirably dark snow surface in which fine density variations are masked. As each user will have a different dyeing need, the dye preparation should begin with a small quantity of methylene coloring - about the volume of a pencil eraser added to a liter of alcohol. Additional coloring can then be added until the optimal snow stratigraphic-morphologic structure highlighting is produced.

\section{SURFACE PREPARATION}

The surface of the snow to be observed should be planed smooth in a manner that limits nicks or chip marks that may collect excess dye on their edges. In a photo, these dyed areas may appear as a natural or load-induced snow structure or an ice lens. A sharp-edged steel scraper was a good surface smoothing device. In hard to reach places, 


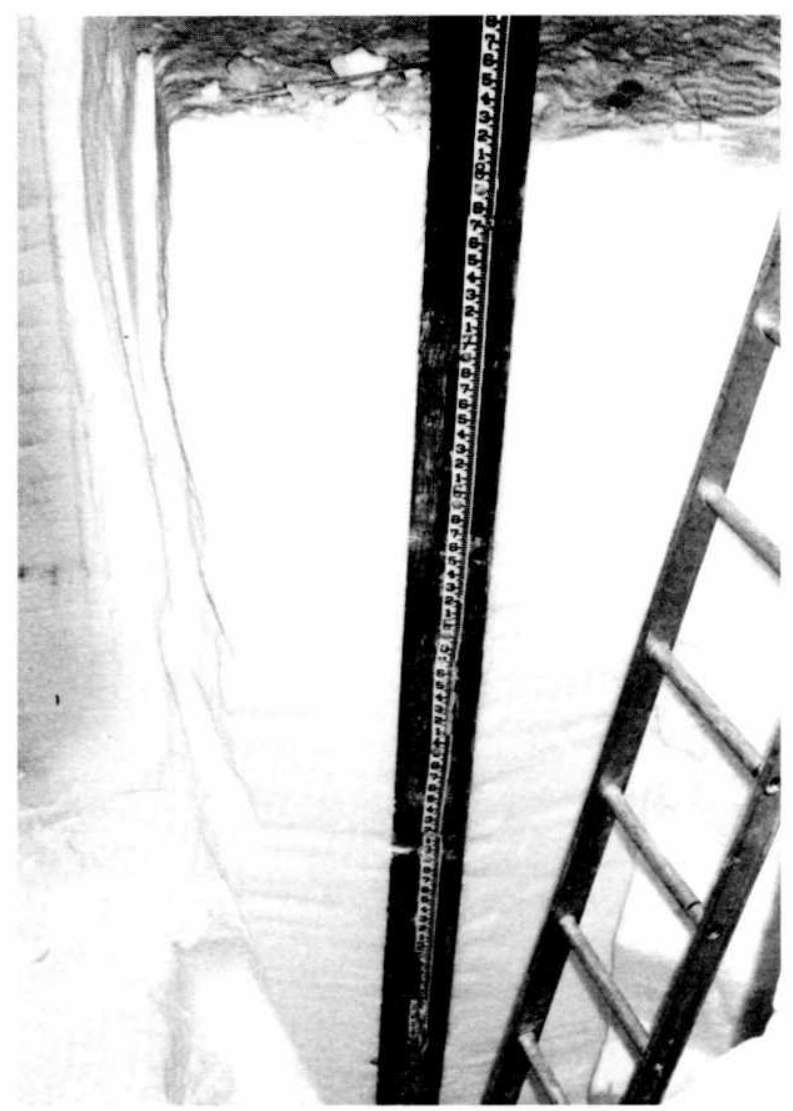

Figure 1. View of exposed 6- $\times 6$-in. $(0.15-\times 0.15-\mathrm{m})$ square timber pile that was driven into $\sim 0.54-\mathrm{Mg} / \mathrm{m}^{3}$ density snow at Camp Century, Greenland. The wavy surface on the pit wall was later removed by scraping with a steel straight-edged tool. Note that no snow stratigraphy can be seen in the photo on either side of the pile.

a stiff putty knife was also helpful. To further improve the surfaces, a stiff paint brush can be used to brush loose fines off the prepared pit wall. In high density snow $\left(>0.45 \mathrm{Mg} / \mathrm{m}^{3}\right)$, a mechanical planing device may be used to remove the more severe gouges and cuts produced by the tools used to excavate the snow pit.

\section{DYE APPLICATION}

An electric spray gun was used in our program to spray the dye uniformly on the prepared surface. If the dye is not applied uniformly, the resulting snow color contrast seen in a photograph could be mistaken for an area of different density. A 1-L hand-held garden sprayer, which is pressur- ized by a built-in hand pump, can be used, provided the pressure is kept up.

\section{IMPROVING VISUAL APPEARANCE}

After the snow surface is dyed, natural stratigraphy and variations in snow density caused by load-induced deformation will be more visible. The structural detail in the snow can be further highlighted by applying a small amount of heat. Heating produces a very thin film of water on the snow surface. This film migrates into the snow pores for a very short distance, carrying the dye and dispersing it into places where it would not otherwise reach.

A blowtorch and an infrared propane heater were used at Camp Century, where the pit snow

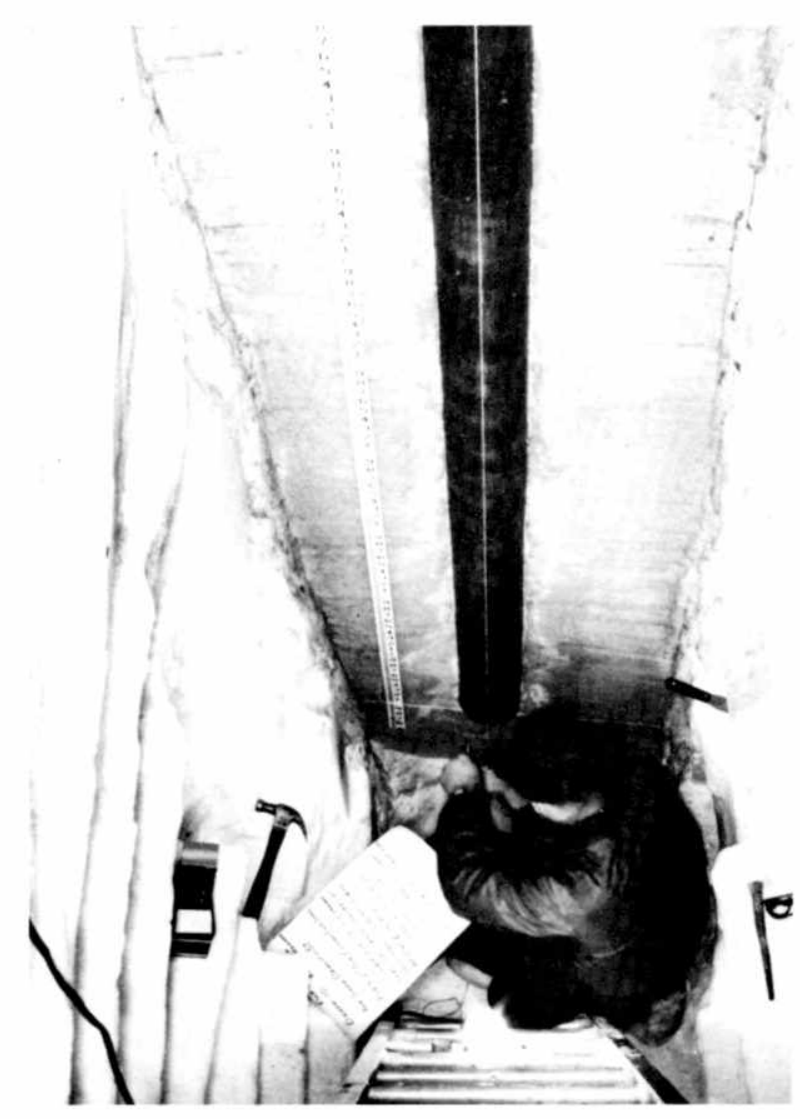

Figure 2. View down into a snow pit that was excavated with an electric chain saw to reveal the snow displacement along a 6-in. (0.15- $m$ ) diameter, closed-ended pipe pile driven into $\sim 0.54-\mathrm{Mg} / \mathrm{m}^{3}$-density snow. After the pit wall was planed smooth and the surface dyed, the natural stratigraphic layering was visible. 
surface temperature was about $-20^{\circ} \mathrm{C}$. A relatively uniform flow of heat (no hot spots) must be applied to the surface. For this reason, the propanefired infrared heater proved best. It is important to understand that only a small amount of heat is needed. Too much heat will glaze the surface or cause the dye to run; glazing will cause the surface to turn white. If either happens, the features that one wishes to observe will no longer be sharp and clear. Heating is probably not needed where the snow temperature is above $-10^{\circ} \mathrm{C}$ or the snow density is less than $0.4 \mathrm{mg} / \mathrm{m}^{3}$.

To obtain a photograph showing sharper snow structure detail, one can auger a hole or cut a trench behind the prepared surface. In tunnels or dark areas, lights can then be placed in the hole to illuminate the snow from behind.

\section{PHOTOGRAPHS OF THE END RESULT}

The following photographs are presented to show that dyed snow pit walls, where the snow density was between 0.5 and $0.6 \mathrm{Mg} / \mathrm{m}^{3}$, give a striking view of the snow structure. Figure 1 shows a snow pit wall surface, beside a square 6$\times 6$-in. $(0.15-\times 0.15-\mathrm{m})$ timber pile, which has not been dyed. It was difficult to distinguish strata, densified snow, etc., from within the pit, and nearly impossible to obtain any stratigraphic information from a photograph of the undyed wall. To the extreme left, however, one can see a darker surface that was lightly dyed. In this area stratigraphic layering is apparent. After dyeing, the natural snow stratigraphy and the snow displaced during pile driving are easily seen, as shown in Figures 24.

Figure 5 is a photo of the block of snow that was removed from around the base of the square timber pile shown in Figure 1. The surface was sprayed with dye and then lit from behind. The snow block was about $0.3 \mathrm{~m}$ thick. Snow displacement patterns that developed during pile driving are clearly visible, as are the natural ice lenses.

Figure 3. Snows stratigraphy and displacement patterns beside a 6-in. $(0.15-m)$ diameter, close-ended steel pile driven $10.1 \mathrm{ft}(3.1 \mathrm{~m})$ below the trench floor. The snow structure was highlighted by illuminating the snow from within a borehole behind the pile. The near vertical dark line on the right side of the pile at about the middle of the composite photo is a chain saw cut.

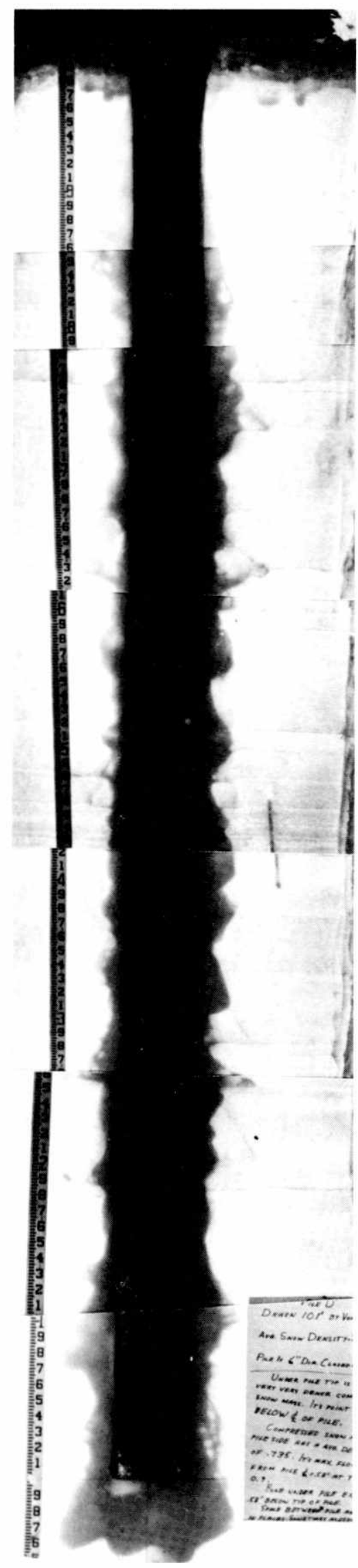




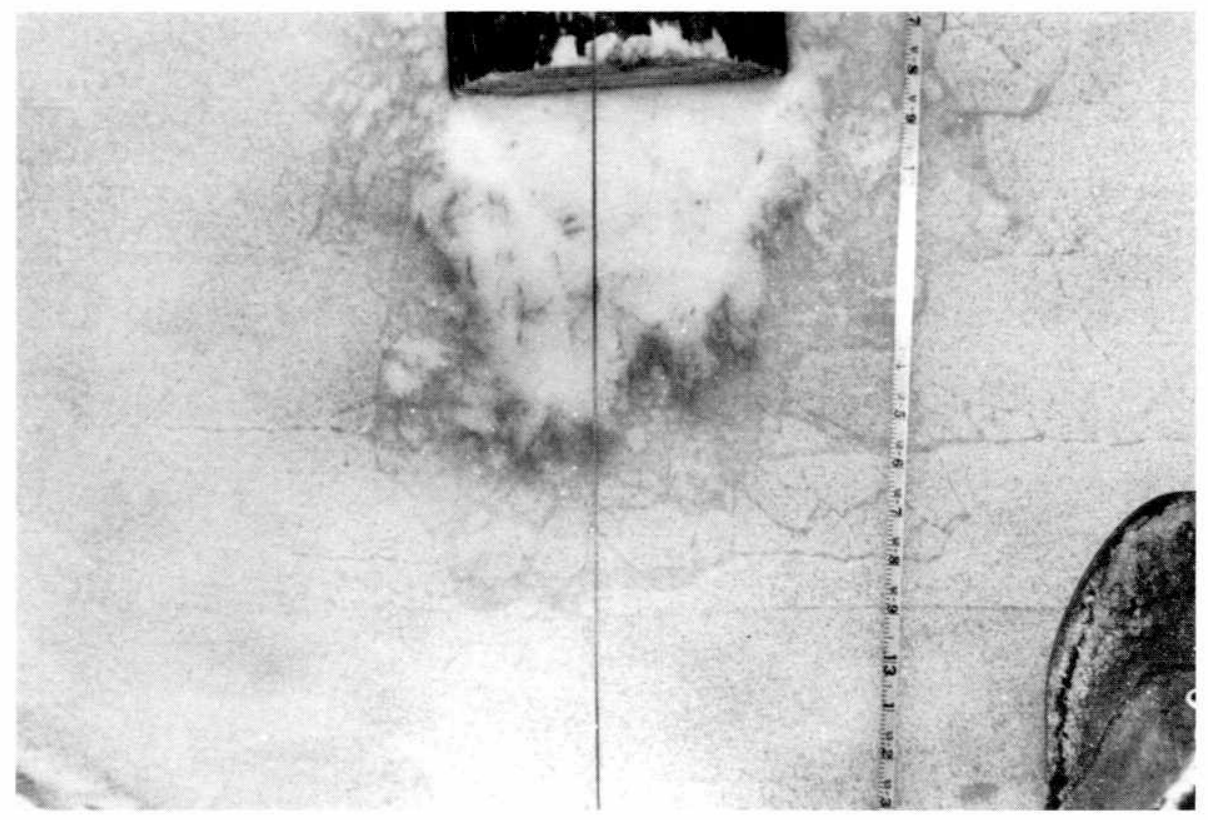

Figure 4. Densified and snow displaced patterns below a tapered timber pile that had been load tested previously.

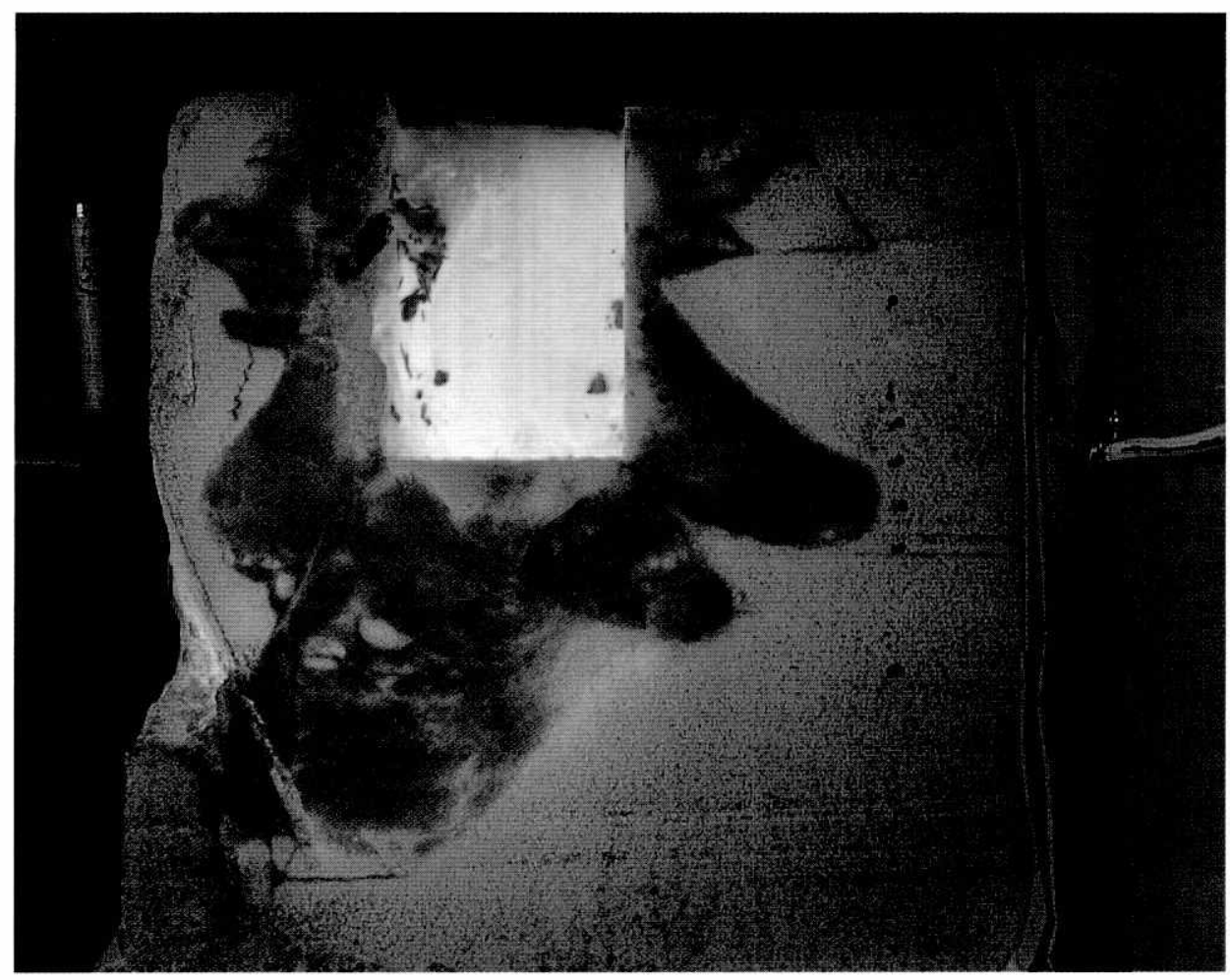

Figure 5. Densified and displaced snow at the base of the 6- $\times 6-i n .(0.15-\times 0.15-\mathrm{m})$ square timber pile shown in Figure 1. The aligned nail heads, at the center right side of the snow block, are spaced $1 \mathrm{in}$. (25.4 mm) apart. This photo was taken using backlighting after the face of the block was dyed. 
Figure 6 shows other pit wall surfaces that were planed smooth and then dyed. One can easily see the natural stratigraphy, as well as the highly densified and displaced snow produced when piles were driven into the snow. The dye did not stain the white areas at the base of the piles shown in Figures 4 and $6 \mathrm{~b}$ because this snow was compressed to a density above $0.85 \mathrm{Mg} / \mathrm{m}^{3}$ and therefore had a very low porosity.

Figure 7a shows a pit surface photographed with floodlights, whereas Figure $7 \mathrm{~b}$ is a view of the same area lighted from behind.

\section{DISCUSSION}

Additional comments that could be made on the piles and snow displacement patterns visible in the above photographs would not be within the scope of this report. Further information may be sought in the report on pile foundations by Kovacs
(1976). The photographs presented here are only intended to give an indication of the results that can be obtained from first planing smooth the surface of a snow pit wall and then applying a dye to reveal snow structure. Each investigator will need to develop, through trial and error, the procedure best suited to producing a good snow surface appearance.

In our field programs, we did not obtain satisfactory results using a dye of methanol coloring in water. Freezeup at the sprayer nozzle was one problem and the snow surface had a blemished appearance because of the addition of the water, which then froze. Freezeup may not be a problem at elevated temperatures, say above about $-3^{\circ} \mathrm{C}$. However, the addition of water to the surface may cause undesirable snow modification. A methylene-colored alcohol dye does not do this because much of the alcohol evaporates.

It should be pointed out that one should be careful when handling the methylene dye

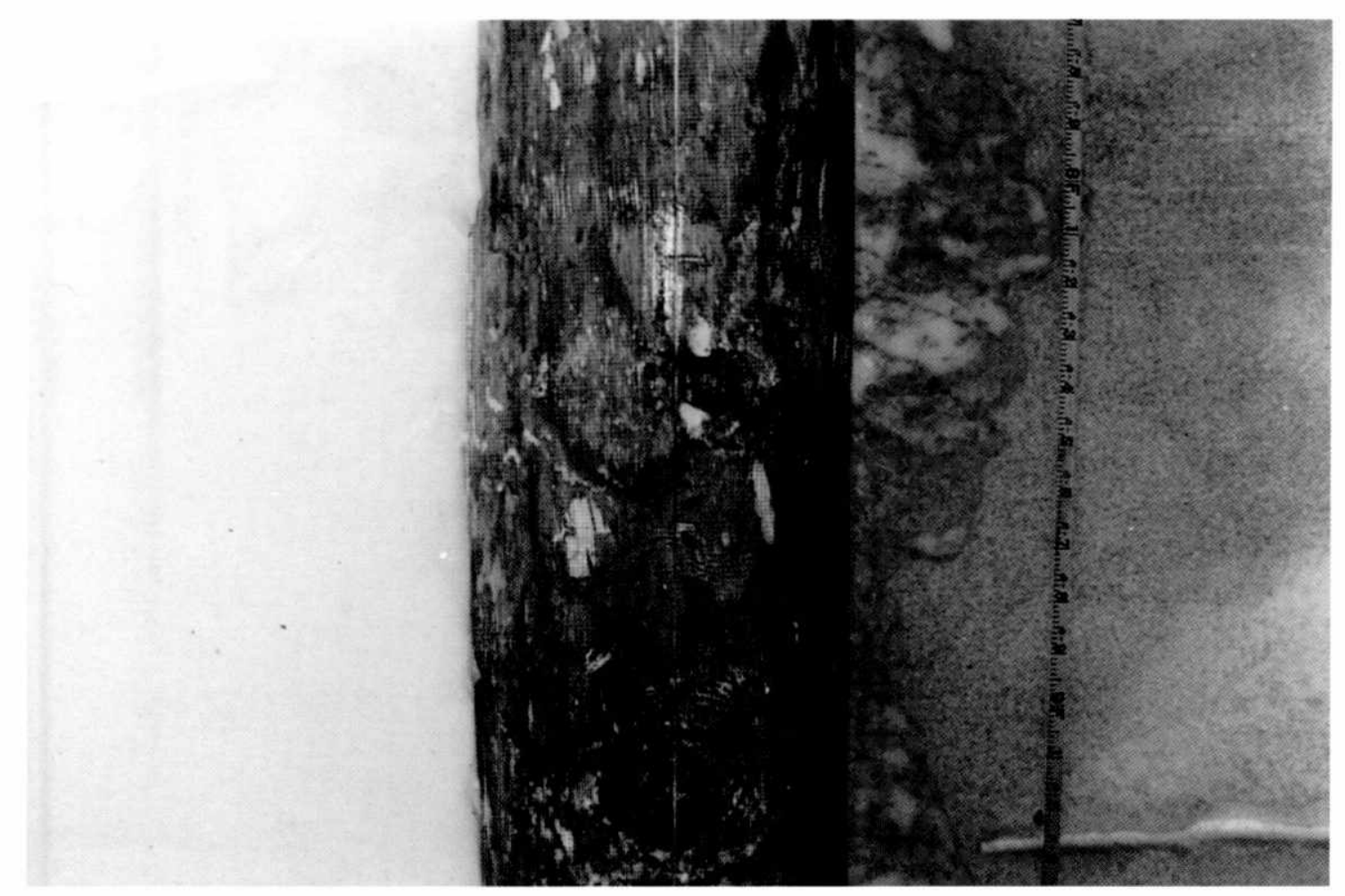

a. Snow morphology beside a tapered timber pile driven into $\sim 0.54-\mathrm{Mg} / \mathrm{m}^{3}$-density snow. Note that where the surface was not dyed (at the upper left), no structure is visible. The horizontal mark near the bottom right is an electric chain saw cut.

Figure 6. Views of dyed pit wall surfaces. 


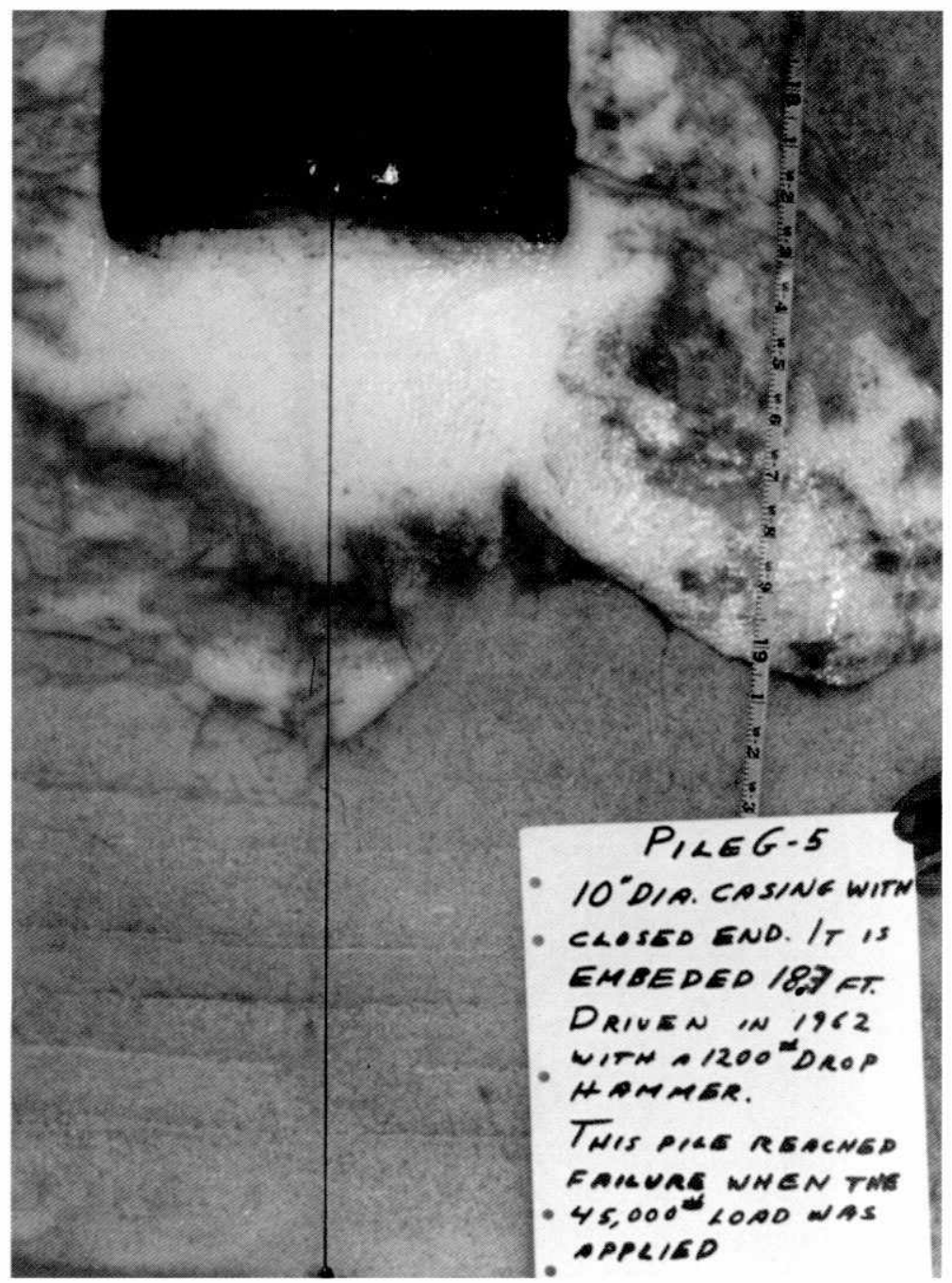

$b$. Densified and displaced snow patterns below a 10-in. (0.25-m) diameter, close-ended steel pile that had been load tested previously.

Figure 6 (cont'd). Views of dyed pit wall surfaces. 

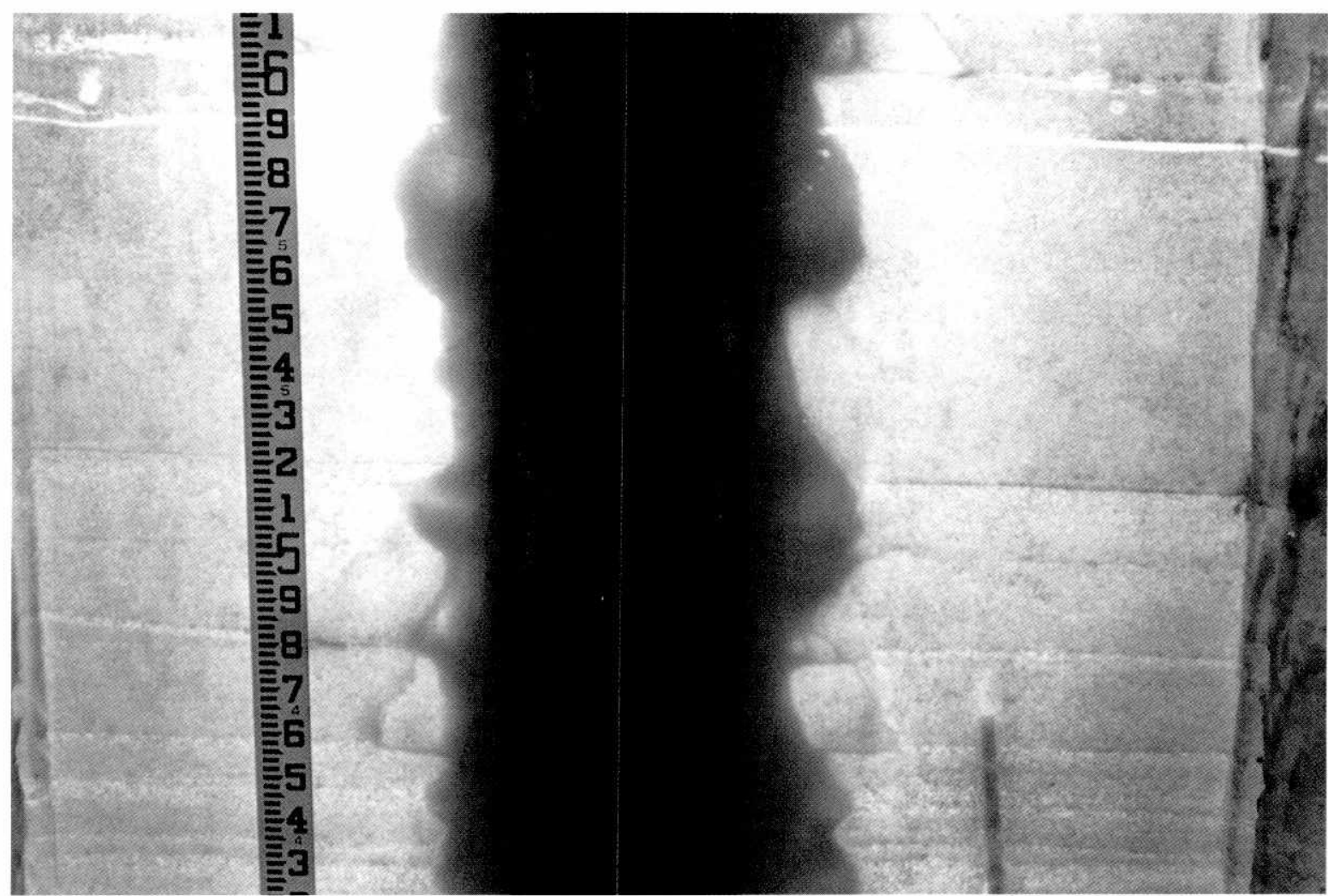

c. An example of the highlighted snow stratigraphy and displacement structure obtained through illuminating the snow from the rear.

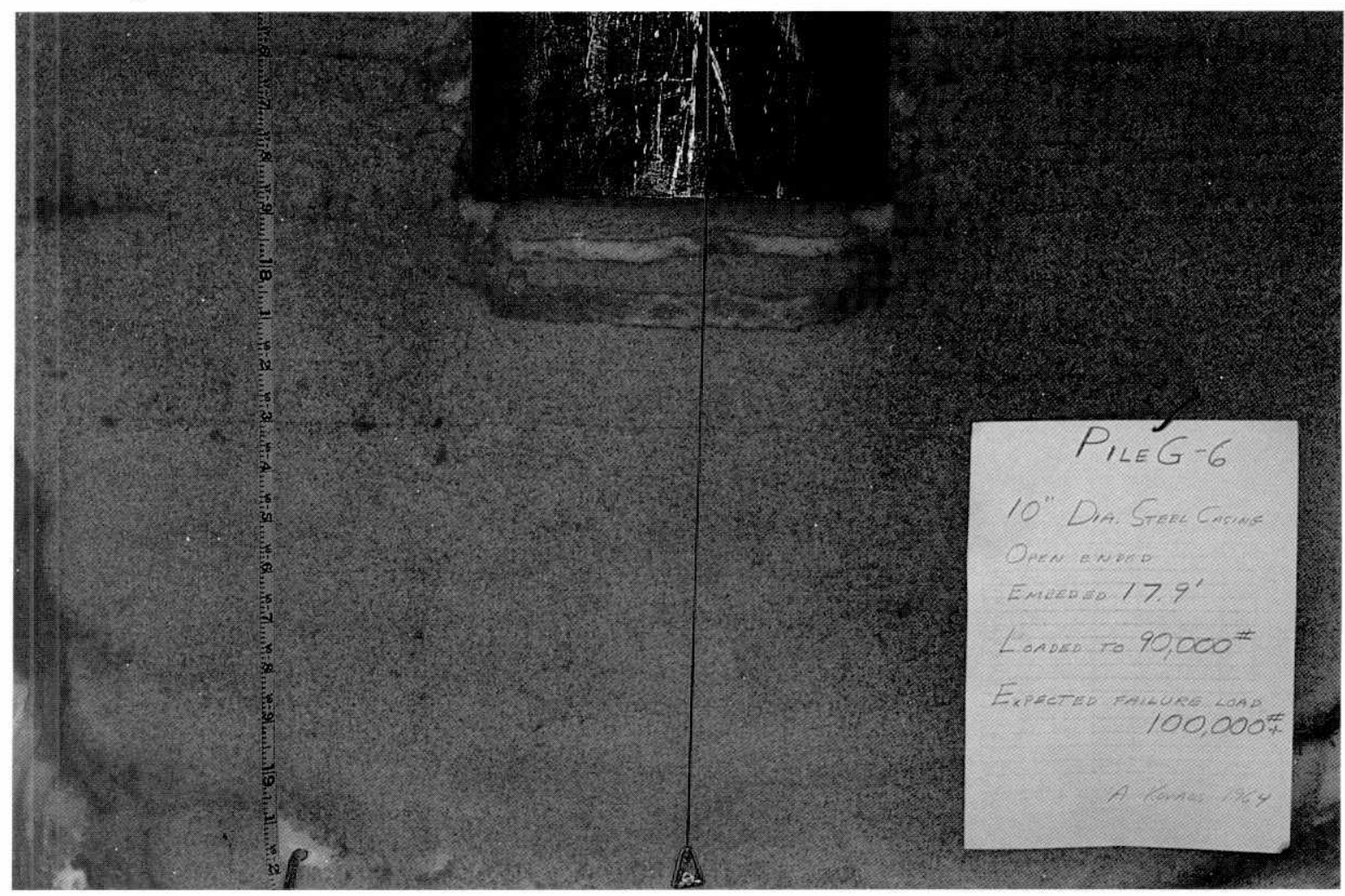

d. Densified and displaced snow patterns along side and below a 10-in. (0.25-m) diameter, open-ended steel pile that had been load tested previously.

Figure 6 (cont'd). 


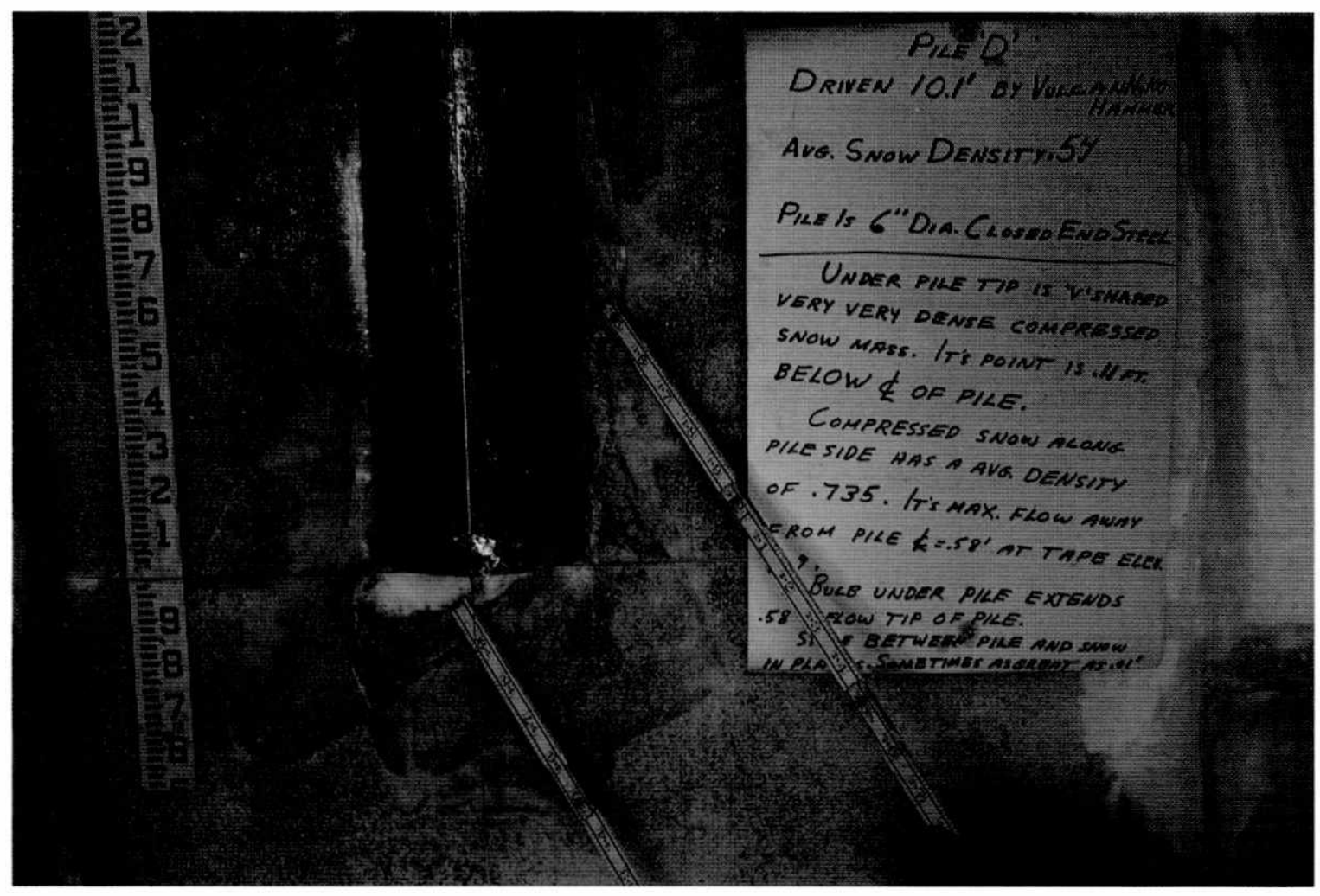

a. Without backlighting.

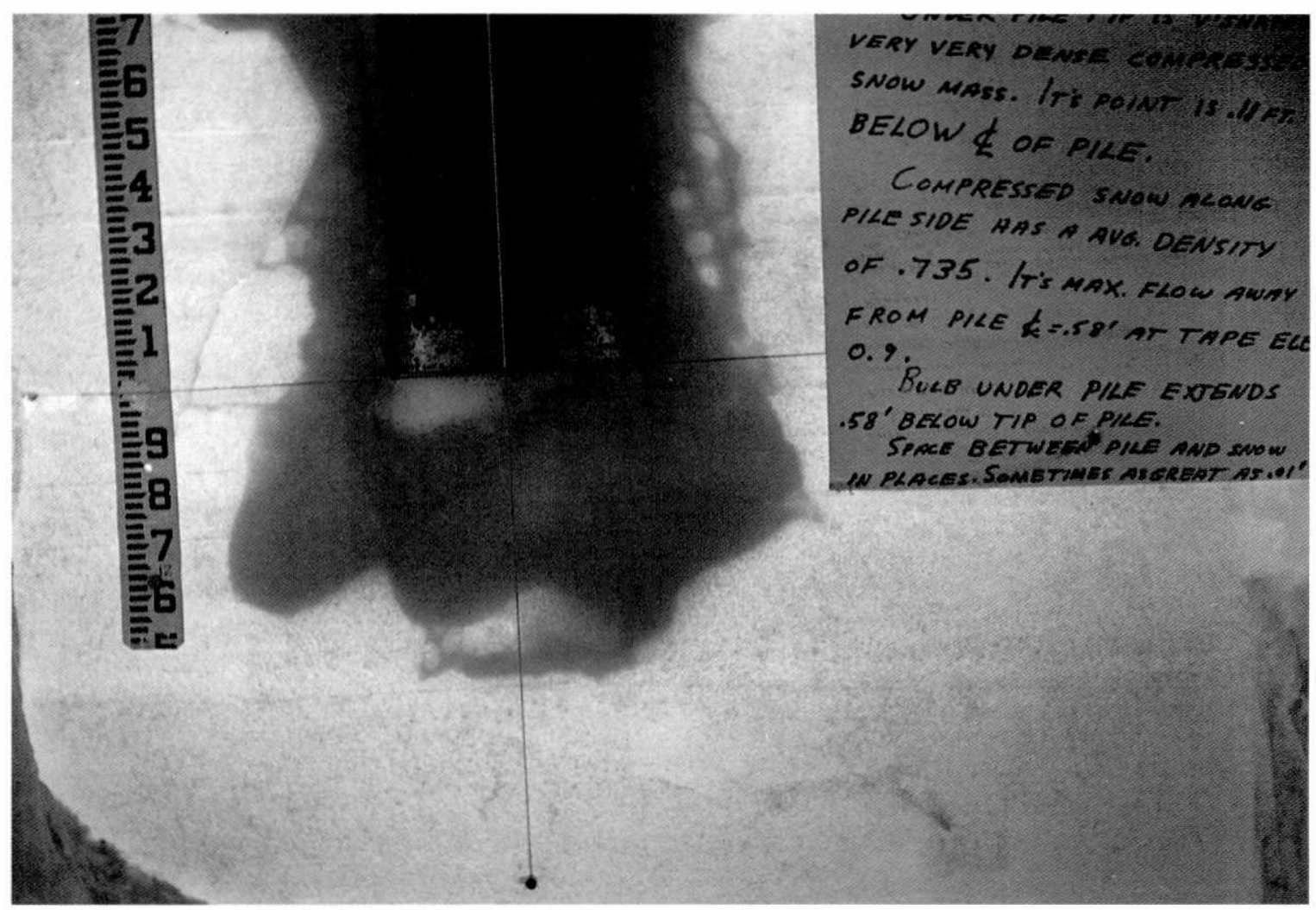

b. With backlighting.

Figure 7. Views of the base area around a 6-in. (0.15-m) diameter, close-ended pile. 
powder; it is a very difficult dye to remove from hands and clothing.

\section{LITERATURE CITED}

Bader, H. (1954) Snow and its metamorphism. USA Snow, Ice, and Permafrost Research Establishment, Translation 14.

Benson, C.S. (1962) Stratigraphic studies in the snow and firn of the Greenland Ice Sheet. USA Cold Regions Research and Engineering Laboratory, Research Report 70.

Kovacs, A. (1967) Feasibility study of buried anchors in polar snow. USA Cold Regions Research and Engineering Laboratory, Special Report 115. Kovacs, A. (1976) Study of piles installed in polar snow. USA Cold Regions Research and Engineering Laboratory, CRREL Report 76-23.

Kovacs, A. and R.O. Ramseier (1968) Effects of solar radiation on processed snow in engineering construction. USA Cold Regions Research and Engineering Laboratory, Technical Report 213.

Diamond, M., H. Bader and J.J. Lanyon (1959) Studies on vehicular trafficability of snow. Part II. USA Snow, Ice, and Permafrost Research Establishment, Technical Report 35.

Reed, S.C. (1966) Spread footing foundations on snow. USA Cold Regions Research and Engineering Laboratory, Technical Report 175. 


\section{REPORT DOCUMENTATION PAGE}

Public reporting burden for this collection of information is estimated to average 1 hour per response, including the time for reviewing instructions, searching existing data sources, gathering and maintaining the data needed, and completing and reviewing the collection of information. Send comments regarding this burden estimate or any other aspect of this collection of information, including suggestion for reducing this burden, to Washington Headquarters Services, Directorate for Information Operations and Reports, 1215 Jefferson Davis Highway, Suite 1204 , Arlington, VA 22202-4302, and to the Office of Management and Budget, Paperwork Reduction Project (0704-0188), Washington, DC 20503.

\begin{tabular}{|l|l|l|}
\hline 1. AGENCY USE ONLY (Leave blank) & $\begin{array}{c}\text { 2. REPORT DATE } \\
\text { June } 1993\end{array}$ & 3. REPORT TYPE AND DATES COVERED \\
\hline
\end{tabular}

4. TITLE AND SUBTITLE

1993

Dyeing of Snow Surfaces to Observe Structure

6. AUTHORS

Austin Kovacs

7. PERFORMING ORGANIZATION NAME(S) AND ADDRESS(ES)

U.S. Army Cold Regions Research and Engineering Laboratory

72 Lyme Road

Hanover, N.H. 03755-1290

9. SPONSORING/MONITORING AGENCY NAME(S) AND ADDRESS(ES)

10. SPONSORING/MONITORING AGENCY REPORT NUMBER

11. SUPPLEMENTARY NOTES

12a. DISTRIBUTION/AVAILABILITY STATEMENT

12b. DISTRIBUTION CODE

Approved for public release; distribution is unlimited.

Available from NTIS, Springfield, Virginia 22161

13. ABSTRACT (Maximum 200 words)

A surface coloring method is described for highlighting the natural stratigraphy and load-induced structure in snow at low ambient temperatures in confined areas. The method includes planing the wall of a snow pit and then dyeing the surface using an alcohol dye applied by an electric sprayer. Surface heating and backlighting are also discussed as methods for revealing hidden detail, especially when photographic evidence of the snow structure is important.

\begin{tabular}{|c|c|c|c|c|c|c|}
\hline \multirow[t]{2}{*}{ 14. SUBJECT TERMS } & \multirow{2}{*}{\multicolumn{2}{|c|}{$\begin{array}{l}\text { Snow coloring } \\
\text { Snow displacement }\end{array}$}} & \multirow{2}{*}{\multicolumn{2}{|c|}{$\begin{array}{l}\text { Snow dyeing } \\
\text { Snow highlighting }\end{array}$}} & \multirow{2}{*}{$\begin{array}{l}\text { Snow morphology } \\
\text { Snow structure }\end{array}$} & $\begin{array}{c}\text { 15. NUMBER OF PAGES } \\
14 \\
\end{array}$ \\
\hline & & & & & & 16. PRICE CODE \\
\hline \multicolumn{2}{|c|}{$\begin{array}{l}\text { 17. SECURITY CLASSIFICATION } \\
\text { OF REPORT }\end{array}$} & \multicolumn{2}{|c|}{$\begin{array}{l}\text { 18. SECURITY CLASSIFICATION } \\
\text { OF THIS PAGE }\end{array}$} & 19. & $\begin{array}{l}\text { JRITY CLASSIFICATION } \\
\text { BSTRACT }\end{array}$ & 20. LIMITATION OF ABSTRACT \\
\hline \multicolumn{2}{|c|}{ UNCLASSIFIED } & \multicolumn{2}{|c|}{ UNCLASSIFIED } & & LASSIFIED & $\mathrm{UL}$ \\
\hline
\end{tabular}

